\title{
Tree-ring growth and intra-annual density fluctuations of Pinus pinaster responses to climate: does size matter?
}

\author{
Filipe Campelo $\cdot$ Joana Vieira $\cdot$ Cristina Nabais
}

Received: 13 June 2012/Revised: 11 December 2012/ Accepted: 12 December 2012/Published online: 30 December 2012

(C) Springer-Verlag Berlin Heidelberg 2012

\begin{abstract}
Dendroclimatology generally assumes that climate-growth relationships are age and size independent. However, there is evidence that climate response can be unstable across different age/size classes. In addition, the occurrence of some anatomical features, such as intraannual density fluctuations (IADFs), is age dependent. The present study investigates whether the climate-growth responses and the occurrence of IADFs in an even-aged stand of Pinus pinaster Ait., growing under Mediterranean climate, are also size-dependent. We randomly selected 60 $P$. pinaster trees falling within two stem diameter classes: small $(<27 \mathrm{~cm})$ and large $(>35 \mathrm{~cm})$. Tree rings were crossdated, measured and IADFs identified according to their position within the ring. The residual chronologies of both size classes were strongly correlated, suggesting a common signal. In fact, similar growth-climate relationships were observed in large and small trees. The frequency of IADFs was higher in large than in small trees, suggesting that IADFs were more likely to occur in wider rings of fast-growing trees. In both size classes, most of the IADFs were found in latewood. Latewood IADFs were triggered by the combination of dry June, wet September, and warm December, whereas IADFs located at the end of earlywood were triggered by previous winter precipitation and favorable conditions before summer (high precipitation for large trees and lower temperature for small trees). Our results suggest that IADFs can be a mechanism used at the
\end{abstract}

Communicated by S. Leavitt.

F. Campelo $(\bowtie) \cdot$ J. Vieira $\cdot$ C. Nabais

Centro de Ecologia Funcional (CFE), Departamento de Ciências

da Vida, Faculdade de Ciências e Tecnologia, Universidade de Coimbra, Apartado 3046, 3001-401 Coimbra, Portugal

e-mail: fcampelo@ci.uc.pt individual level for adaptation to drought in $P$. pinaster. The climatic signal of IADFs between earlywood and latewood was mediated by stem size suggesting that future tree-ring studies should include trees stratified by size to better estimate the sensitivity of IADFs to climate.

Keywords Tree size $\cdot$ IADFs $\cdot$ False rings ·

Mediterranean climate $\cdot$ Ecological wood anatomy

\section{Introduction}

Dendroclimatology is based on the assumption that climate-growth relationships are age independent, once the biological growth trends and the effect of competition have been removed (Szeicz and MacDonald 1994). Therefore, dendroclimatologists have a tendency to prefer old, dominant and isolated trees (Meyer and Braker 2001). However, tree-ring growth and its climatic signal may change across different age/size classes (Carrer and Urbinati 2004; He et al. 2005; Wang et al. 2009; Griffin et al. 2011; Xing et al. 2012), with literature giving contradictory findings. Chhin et al. (2008) found that different diameter classes of Pinus contorta Dougl. had a similar response to climate. A common climatic signal was also found among different age classes of Pinus cembra L. in the central European Alps (Esper et al. 2008). However, other studies have shown evidence that the climatic signal of ring-width series is not always independent of age/size and may reflect physiological changes related to ageing (Szeicz and MacDonald 1994). Yu et al. (2008) described a stronger climate signal in older trees of Sabina przewalskii Kom., but differences among age classes were less evident for trees older than 200 years. De Luis et al. (2009) found that climate-growth relationships were mediated by tree size, with 
small diameter trees being more sensitive to climate. However, tree size usually increases with age making it difficult to separate their respective influences on tree growth.

Wimmer (2002) pointed out the need to incorporate intra-ring features or anomalies in radial growth as an additional source of ecological and climatological information. An example of these intra-ring features are the intra-annual density fluctuations (IADFs) of conifers species (Rigling et al. 2001; Masiokas and Villalba 2004). IADFs reflect short-term changes in the cambial activity of a tree throughout the growing season (Campelo et al. 2007; Edmondson 2010), which in turn is controlled by genetic and environmental conditions. Xylogenesis, or wood formation, starts with periclinal cell divisions of the vascular cambium, followed by cell expansion, cell-wall thickening and lignification, and ends with the autolysis of the cell contents (Larson 1994). Early in the growing season, when water and nutrient reserves are abundant, active cell division in the cambium forms earlywood tracheids. As the season progresses and water becomes less abundant, cambial activity slows down and latewood tracheids are produced (Uggla et al. 2001). The percentage of earlywood and latewood within a single ring has a strong effect on water transport, storage and vulnerability to embolism (Domec and Gartner 2002). Frequently, tree rings of conifers deviate from the typical earlywood-latewood pattern, with the formation of latewood-like cells within earlywood or earlywood-like cells in latewood, the socalled IADFs.

The position of IADFs within tree rings and their frequency can be used to study climatic variability within the growing season (Campelo et al. 2007; de Luis et al. 2011; de Micco et al. 2012), in particular in regions with a long growing season, such as low altitude sites in the Mediterranean Basin. Strong relationships between IADF formation and climate have been obtained in different species of the genus Pinus (Wimmer et al. 2000; Rigling et al. 2001; Campelo et al. 2007; de Luis et al. 2009; Vieira et al. 2009; Rozas et al. 2011). In the Iberian Peninsula, latewood density fluctuations in Pinus pinea L. (Campelo et al. 2007), Pinus halepensis Mill. (de Luis et al. 2007) and Pinus pinaster Ait. (Vieira et al. 2009; Rozas et al. 2011) were triggered by late-summer or autumn rainfall. The consistency of the climatic signal among different pine species and areas suggests that, in the future, a large-scale network of IADFs could be developed in the Mediterranean region to study intra-annual climate variability. MartinezMeier et al. (2008) pointed out that the variation in latewood characteristics (density and width) of Douglas-fir, mostly in the outermost rings, may be related to drought resistance, helping trees to maintain the integrity of their hydraulic systems. However, they did not assess the effect of IADFs on resistance to drought, but one can expect that intra-ring variations of wood density may have an impact on conductive capacity and on vulnerability to cavitation (Domec and Gartner 2002).

The frequency of IADFs can also be age and size dependent. Vieira et al. (2009), working with two age classes, showed that younger trees of $P$. pinaster growing on a sand dune ecosystem in Portugal had a higher frequency of IADFs than older trees. Hoffer and Tardif (2009) pointed out that IADFs were more frequent in the youngest rings (i.e., those close to the pith). However, no approach has yet been applied to separate the effect of age and size on IADF formation. Even-aged forest stands with different stem sizes give us the opportunity to evaluate the effect of tree size on IADF formation, while age is controlled.

In the present study, we investigated whether tree-ring growth and IADF responses to climate were mediated by stem size in an even-aged stand of $P$. pinaster growing in a sand dune ecosystem under a Mediterranean climate.

\section{Materials and methods}

Study site

The study area was in an even-aged managed forest of $P$. pinaster in Perimetro Florestal Dunas de Cantanhede, located in the central coast of Portugal (Fig. 1). The climate is typically Mediterranean with oceanic influence, mild winters and warm dry summers. Monthly climate data (mean temperature and precipitation) of the closest grid point were obtained from the Royal Netherlands Meteorological Institute web site (http://www.climexp.knmi.nl/). For the period 1960-2008, the mean annual temperature in the study area was $16.0{ }^{\circ} \mathrm{C}$ and the annual precipitation was $983 \mathrm{~mm}$, with ca. $80 \%$ of the yearly precipitation falling between October and April (Fig. 1). The average winter (December-February) and summer (June-August) temperatures were 11.6 and $21.2{ }^{\circ} \mathrm{C}$, respectively. Soils were acidic with sandy texture and low nutrient-holding capacity.

Tree-ring chronologies

Pinus pinaster has its natural distribution in the western Mediterranean Basin, and is one of the most important tree species in Portugal (Pereira 2002). It is a fast growing species with drought- and salt-resistance and, therefore, has been cultivated to stabilize sand dunes. In 2009, 120 dominant and co-dominant trees were randomly selected and their diameter at breast height measured to obtain the distribution of trees' diameter in the study area (Fig. 2). According to the cumulative distribution of trees diameter, 
Fig. 1 Location of the study site (filled circle) and the climate diagram obtained using data from the closest grid point (http://www.climexp.knmi.nl/). Climate diagram utilizes box and whisker plots to show the distribution of monthly precipitation for the period 1960-2008. The "box" represents the interquartile range (middle $50 \%$ ) with the horizontal line indicating the median. The whiskers give a broader picture of the range of the data and the length of each whisker is 1.5 times the interquartile range. Values falling outside of the whiskers are considered as outliers (open circles)

Fig. 2 Cumulative frequency by stem diameter of 120 Pinus pinaster trees randomly selected. In 2009, around onethird of the trees in this area had diameters smaller than $27 \mathrm{~cm}$, whereas approximately onethird was larger than $35 \mathrm{~cm}$. Vertical lines indicate the diameters of trees used in the present study
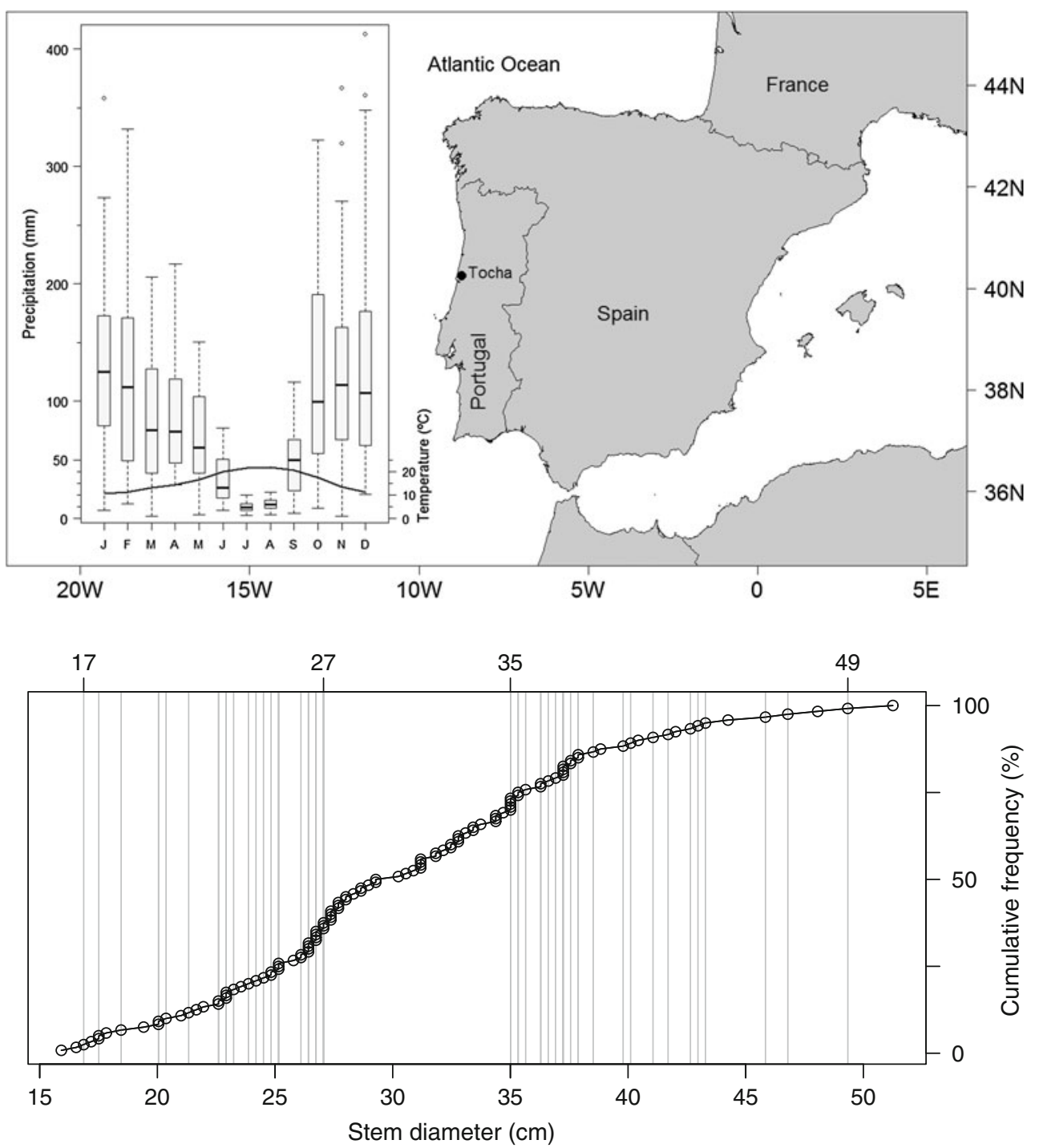

approximately $1 / 3$ of trees had diameter inferior to $27 \mathrm{~cm}$ and $1 / 3$ had diameter $>35 \mathrm{~cm}$ (Fig. 2). To test whether climatic response is size-mediated, 2 groups of 30 trees each were sampled according to the stem diameter: small $(23.9 \pm 3.0 \mathrm{~cm})$ and large $(38.7 \pm 3.9 \mathrm{~cm})$. To account for potential tree-ring growth variability around the stem, two cores in the north-south direction were extracted from each tree, at breast height as close as possible to the pith, using an increment borer. The cores were air-dried, mounted on wooden supports, and sanded with progressively finer sandpaper to produce a flat surface on which tree-ring boundaries were clearly visible under magnification.

Tree rings were visually crossdated using standard dendrochronological techniques (Stokes and Smiley 1996). Tree-ring widths were measured to the nearest $0.01 \mathrm{~mm}$ using a linear table, LINTAB ${ }^{4}$ (Frank Rinn S.A., Heidelberg, Germany, http://www.rinntech.com) and the program TSAP-Win (Rinn 2003). Cambial age at the coring height was determined by the number of annual rings when samples showed the pith. For each size class, all cores showing the pith were used to determine the mean radial width of the ten inner rings. With these values, a circular graph was obtained and whenever a sample did not have the pith, its location and the number of missing rings were extrapolated using this circular graph (Liu 1986). A common overlap period from 1955 to 2008 was used to compare tree-ring width between size classes. The $t$ test was used to test if cambial age at the breast height was different between size classes.

To remove age-related growth trends and competition effects, a one-step detrending was applied to each individual series, using the packages “dplR" (Bunn 2008) and "detrendeR" (Campelo et al. 2012) for the R freeware program (http://www.cran.r-project.org). A smoothing cubic spline curve with a $50 \%$ frequency cut-off and response period of 40 years was fitted to each individual ring-width series. Autoregressive modeling was performed on each standardized series to remove temporal 
autocorrelation, to maximize the climatic signal. Finally, size class chronologies were obtained by averaging residual series using a biweight robust estimate of the mean to reduce the influence of outliers (Briffa and Jones 1990). The mean sensitivity (MS) and the first-order autocorrelation (AR1) were calculated on the detrended individual index series and averaged to measure the year-to-year variability and how the current-year growth was affected by the previous-year growth, respectively. Chronology quality was evaluated using the expressed population signal (EPS) that indicates the degree to which a given chronology approaches a hypothetically perfect chronology (Wigley et al. 1984).

Intra-annual density fluctuations

The visual identification of IADFs was made on accurately dated cores, using a stereomicroscope (magnification up to $25 \times$ ). IADFs were easily distinguishable from annual treering boundaries by the gradual transition in cell size and wall thickness at the outer borders of these anatomical structures (Fig. 3). IADFs were identified by considering the position of the density fluctuation within the ring (Campelo et al. 2007). The IADF type $\mathrm{E}$ was characterized by latewood-like cells within earlywood (in the first $1 / 2$ of the ring), whereas the IADF type $\mathrm{E}^{+}$was identified as a band of latewood-like cells at the end of the earlywood, corresponding to a gradual transition between earlywood and latewood. The IADF type L was considered when earlywood-like cells were within the latewood (in the second $1 / 2$ of the ring), whereas the IADF type $\mathrm{L}^{+}$showed earlywood like cells between latewood and earlywood of the next tree ring (Fig. 3). In the case of IADF $\mathrm{L}^{+}$, it is not considered as latewood-like cells at the beginning of the next ring, since the transition between latewood and the earlywood-like cells is gradual, whereas the transition from IADF $\mathrm{L}^{+}$to the next ring (earlywood) is abrupt. The relative frequency of IADFs per year, $F$, was calculated as the ratio:

$F=\mathrm{N} / n$

where $N$ is the number of cores showing the same type of IADF in a given year, and the $n$ is the number of cores in that year. To correct the bias generated by the changing sample depth over time, a stabilized IADF frequency, $f$, was calculated as:

$f=F n^{0.5}$

where $F$ is the relative frequency of IADFs (Osborn et al. 1997). Paired $t$ tests were used specifically to test the difference in occurrence of IADFs between small and large trees.
Climatic signal in tree-ring width and IADFs

For the period 1960-2008, the influence of climatic variables (mean air temperature and precipitation), from November of the previous year $(t-1)$ to December of the current year $(t)$, on tree-ring width and frequency of IADFs was investigated using bootstrapped correlation coefficients of Pearson's and Spearman's, respectively. The correlation coefficients were computed using 9,999 bootstrapped samples with replacement. The significance of each correlation coefficient is provided by the ratio between the average value estimated from all simulations and its standard deviation. A correlation coefficient was considered significant at the level of 0.05 when the absolute value of the ratio was $\geq 2$. For variables showing significant correlations for consecutive months, bootstrap correlations were also calculated for seasonal variables.

\section{Results}

The cambial age of both size classes shows no significant differences $(t=-0.913$, df 58, $p=0.365)$. The raw and the residual chronologies of both size classes show a similar tree-ring width pattern and residual chronologies are strongly correlated ( $r=0.89, p<0.001$, Fig. 4). The raw chronologies showed that the rings of large trees are significantly wider than those of small trees $(t=-11.861$, $d f 53, p<0.001$ ). The first-order autocorrelation (AR1) was high (0.53-0.60), meaning that the tree-ring width in a given year is partially explained by the growth conditions during the previous year. The high values of MS and EPS (Table 1) are indicative of high levels of common variance and suggest that tree growth is controlled by climatic factors.

Tree-ring width is positively correlated with precipitation between November $(t-1)$ and February in both size classes (Fig. 5). During the growing season, April-July precipitation enhances tree growth. Growth is positively correlated with temperatures in $\operatorname{December}_{(t-1)}$ and September in both size classes, while smaller trees also show a positive and negative correlation with the temperatures of February and July, respectively.

The distribution of the stabilized IADF frequencies in relation to calendar years is shown in Fig. 6. For both size classes, the distribution of IADF $\mathrm{E}$ is not shown because this type of IADF was not frequent $(<1 \%$; Table 2$)$. IADF $\mathrm{E}^{+}$was less frequent than latewood IADFs $\left(\mathrm{L}\right.$ and $\left.\mathrm{L}^{+}\right)$for both size classes. The stabilized frequency of IADFs was higher in large than in small trees (type $\mathrm{E}^{+}, t=-4.598, d f$ $53, p<0.001$; type L, $t=-3.935$, df 53, $p<0.001$; type $\left.\mathrm{L}^{+}, t=-3.331, d f 53, p<0.01\right)$. 


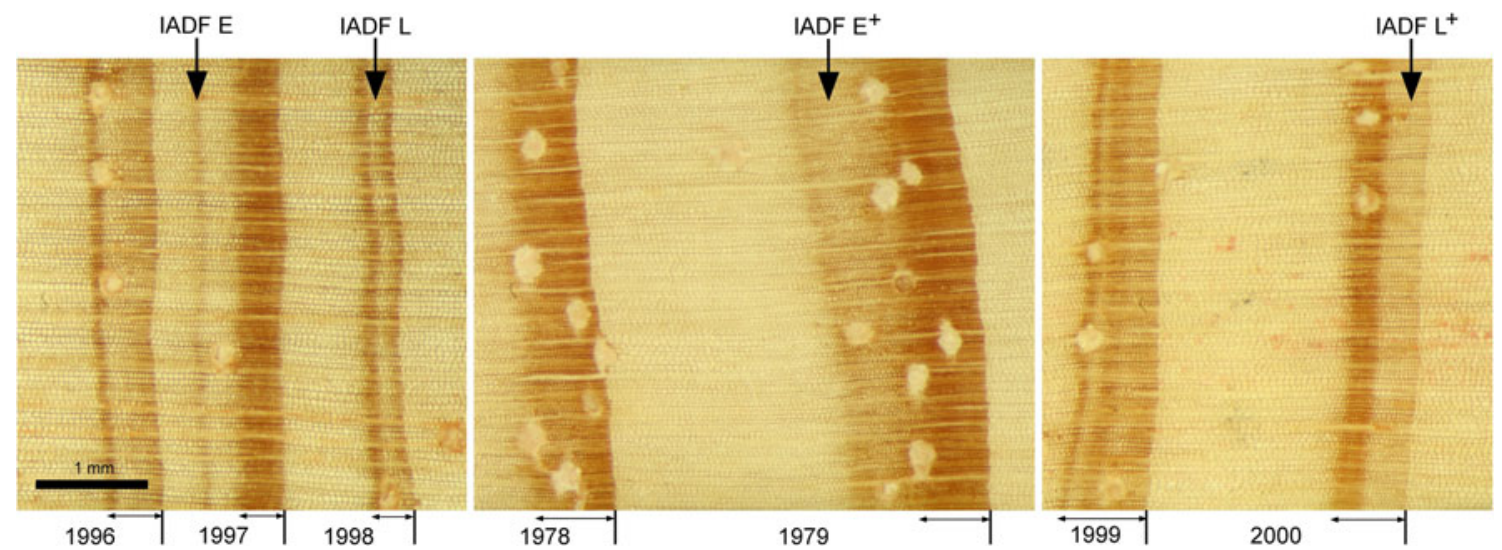

Fig. 3 Different types of intra-annual density fluctuations (IADFs) in Pinus pinaster defined according to their relative position within the ring: type $\mathrm{E}$ is within earlywood (in the first $1 / 2$ of the ring), type $\mathrm{E}^{+}$is located between earlywood and latewood (gradual transition from earlywood to latewood), type $\mathrm{L}$ is within latewood and type $\mathrm{L}^{+}$ is located at the end of latewood (the transition from latewood to earlywood-like cells is more gradual than the transition from

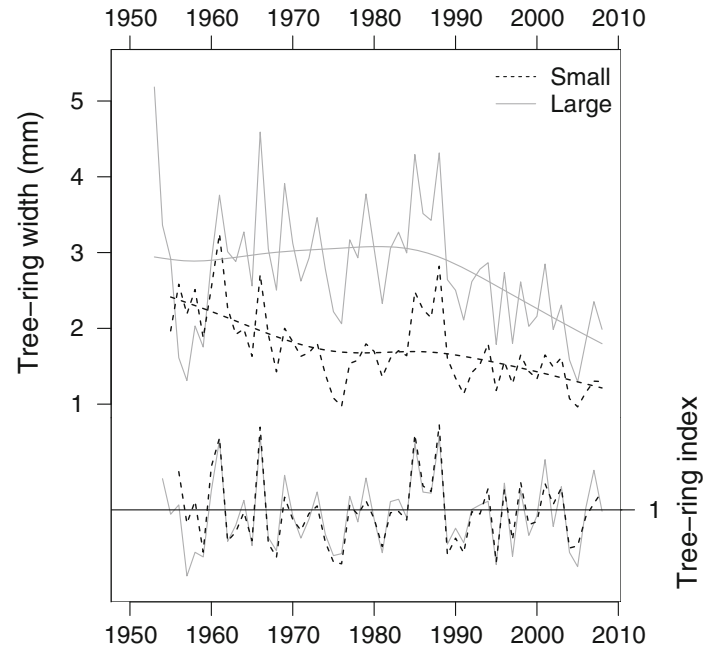

Fig. 4 Raw (upper panel) and residual (lower panel) ring-width chronologies of small (dashed line) and large (solid line) size classes. A spline with 40 years length was fit to each raw ring-width chronology to better illustrate the age trend of both size classes

Climatic factors triggering the formation of IADF type $\mathrm{E}^{+}$were different between the two size classes (Fig. 7). In larger trees, December $(t-1)$ and June precipitation triggered the formation of IADF $\mathrm{E}^{+}$. In smaller trees, IADF $\mathrm{E}^{+}$ was positively correlated with January precipitation and negatively correlated with September and December ${ }_{(t)}$ precipitation, and negatively correlated with June, July and August temperature and positively correlated with October temperature. For both size classes, the formation of IADF type L was associated with low precipitation in Novem$\operatorname{ber}_{(t-1)}$ and June, high precipitation in September and above average temperature in $\operatorname{December}_{(t)}$. In the case of larger trees, the IADF type L was also associated with low earlywood-like cells to "true earlywood" of the next ring). Annual tree rings grew from left to right and arrows indicate the position of IADFs within tree rings. Below the photographs, vertical lines show tree-ring boundaries, horizontal double-head arrows indicate latewood and the calendar year assigned to each ring is provided for rings showing latewood

Table 1 Descriptive statistics of tree-ring width chronologies

\begin{tabular}{lll}
\hline & Small & Large \\
\hline Time period & $1955-2008$ & $1953-2008$ \\
No. of trees (no. of radii) & $30(60)$ & $30(60)$ \\
Mean (mm) & 1.72 & 2.82 \\
Mean sensitivity & 0.30 & 0.30 \\
SD & 0.85 & 1.30 \\
First-order autocorrelation & & \\
$\quad$ Raw series & 0.60 & 0.53 \\
Interval analysis (1960-2008) & & \\
$\quad$ No. of trees (no. of radii) & $11(21)$ & $9(13)$ \\
EPS & 0.92 & 0.88 \\
Rbt & 0.45 & 0.41 \\
\hline
\end{tabular}

$S D$ standard deviation, EPS express population signal, rbt mean correlation between trees

precipitation in December $(t-1)$ and January and low temperature in September. Small trees also show a positive correlation with October precipitation. Both size classes produced IADF type $\mathrm{L}^{+}$in response to below-average precipitation in June and above-average temperature in August and December ${ }_{(t)}$. Larger trees also responded negatively to January precipitation, but positively to Decem-

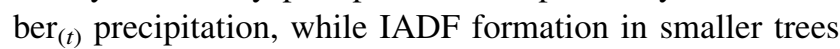
positively correlated with temperature in $\operatorname{December}_{(t-1)}$.

\section{Discussion}

The climatic response of trees can be size-mediated with some studies showing higher sensitivity in larger trees (Mérian and Lebourgeois 2011) or in smaller trees (Pichler 


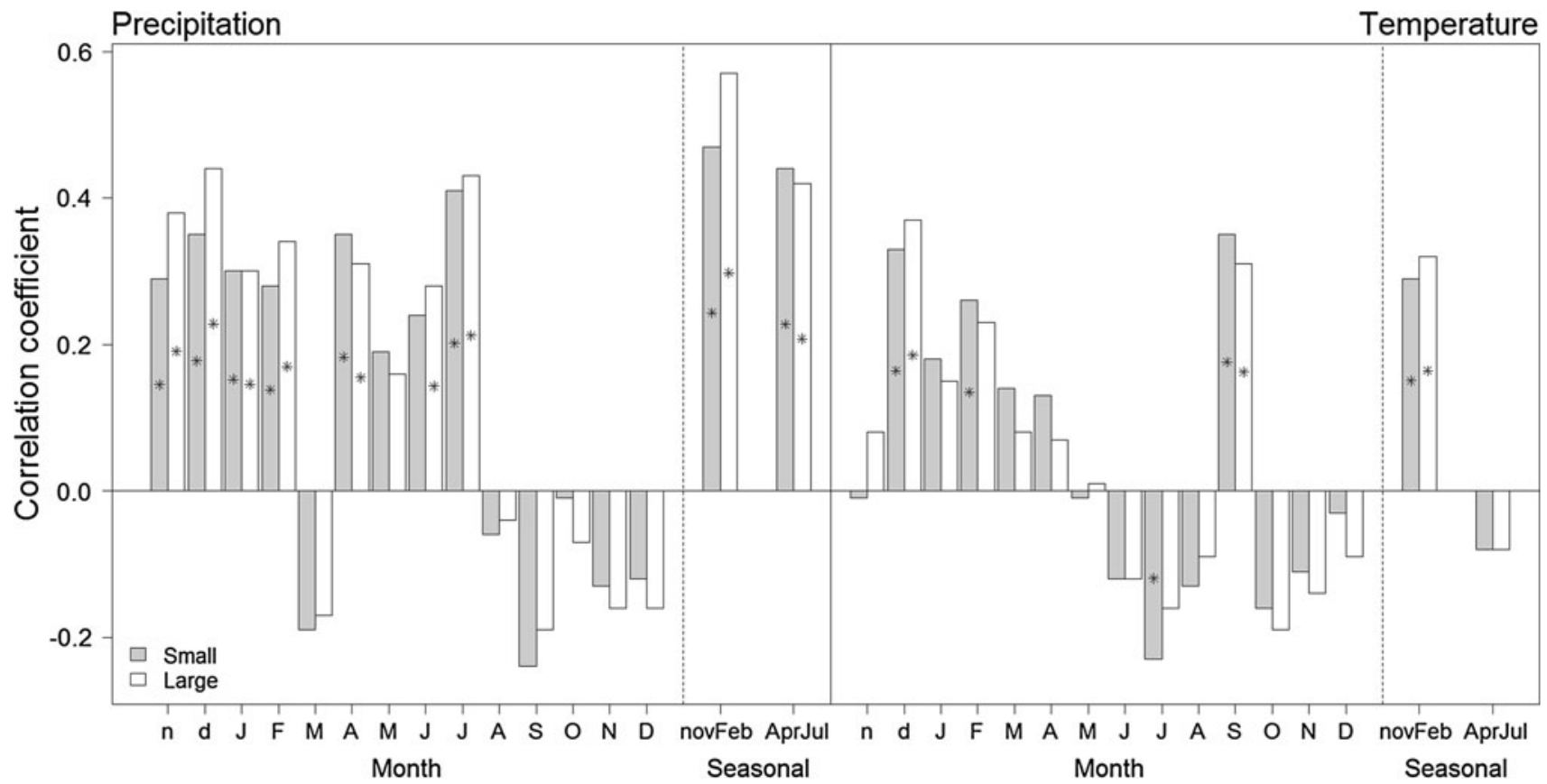

Fig. 5 Bootstrapped correlation coefficients between tree-ring width residual chronologies of Pinus pinaster and monthly/seasonal precipitation (left) and temperature (right) data from previous November to December of current year, for the period 1960-2008.

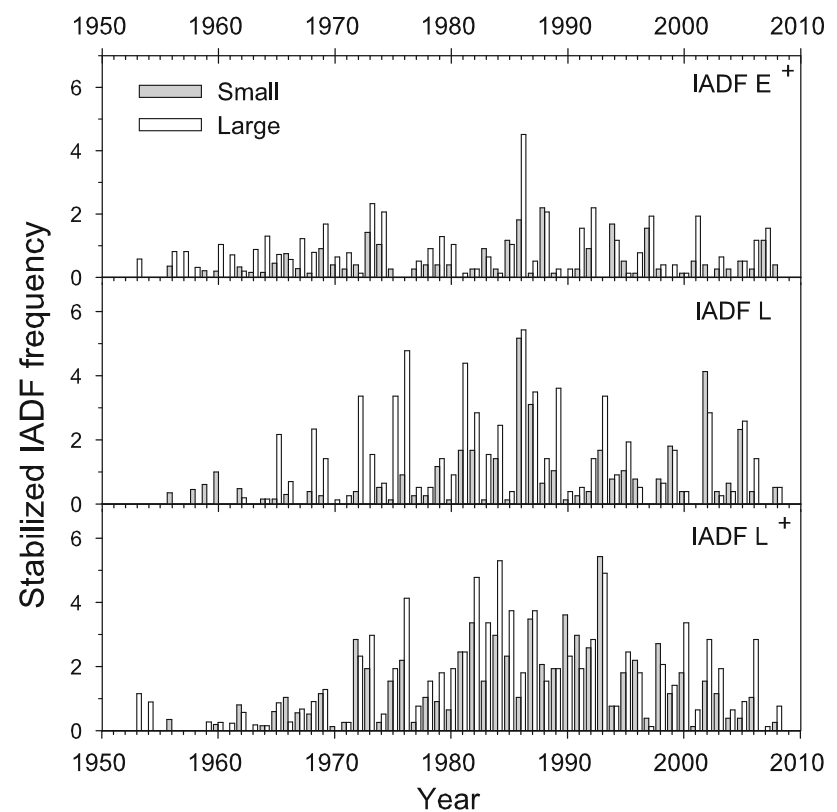

Fig. 6 Stabilized frequency of intra-annual density fluctuations (IADF E ${ }^{+}$, IADF L and IADF $\mathrm{L}^{+}$) for small and large diameter trees in relation to calendar years

and Oberhuber 2007; de Luis et al. 2009), although other studies showed no significant differences (Meyer and Braker 2001; Chhin et al. 2008). According to our data, tree-ring width of large and small trees of $P$. pinaster showed a similar response to climate, with positive
An asterisk indicates a significant correlation at $p<0.05$. Lowercase prior-year months, capitals current-year months, novFeb, prior November to current February, AprJul April to July

Table 2 Descriptive statistics of the intra-annual density fluctuations (IADFs) for both size classes

\begin{tabular}{lll}
\hline & Small & Large \\
\hline No. of trees (no. of cores) & $30(60)$ & $30(60)$ \\
No. of rings analyzed & 2,842 & 2,792 \\
No. of rings showing IADFs & 943 & 1,340 \\
Rings with IADFs (\%) & 33.18 & 47.99 \\
Rings with IADF E (\%) & 0.67 & 0.54 \\
Rings with IADF E ${ }^{+}(\%)$ & 6.65 & 11.71 \\
Rings with IADF L (\%) & 10.38 & 19.23 \\
Rings with IADF L ${ }^{+}(\%)$ & 18.58 & 24.14 \\
Interval analysis (1960-2008) & & \\
No. of rings analyzed & 2,770 & 2,743 \\
No. of rings showing IADFs & 934 & 1,328 \\
Rings with IADFs (\%) & 33.72 & 48.41 \\
Rings with IADF E (\%) & 0.69 & 0.47 \\
Rings with IADF E ${ }^{+}(\%)$ & 6.75 & 11.7 \\
Rings with IADF L (\%) & 10.43 & 19.58 \\
Rings with IADF L ${ }^{+}(\%)$ & 19.03 & 24.39 \\
\hline
\end{tabular}

correlations for winter (November $(t-1)$ to February) and spring precipitation. In both size classes, the temperature between November $_{(t-1)}$ and February was positively correlated with tree-ring width, probably reflecting the limiting effect of winter temperature on the photosynthesis of Mediterranean pines (Rathgeber et al. 2005). Several 


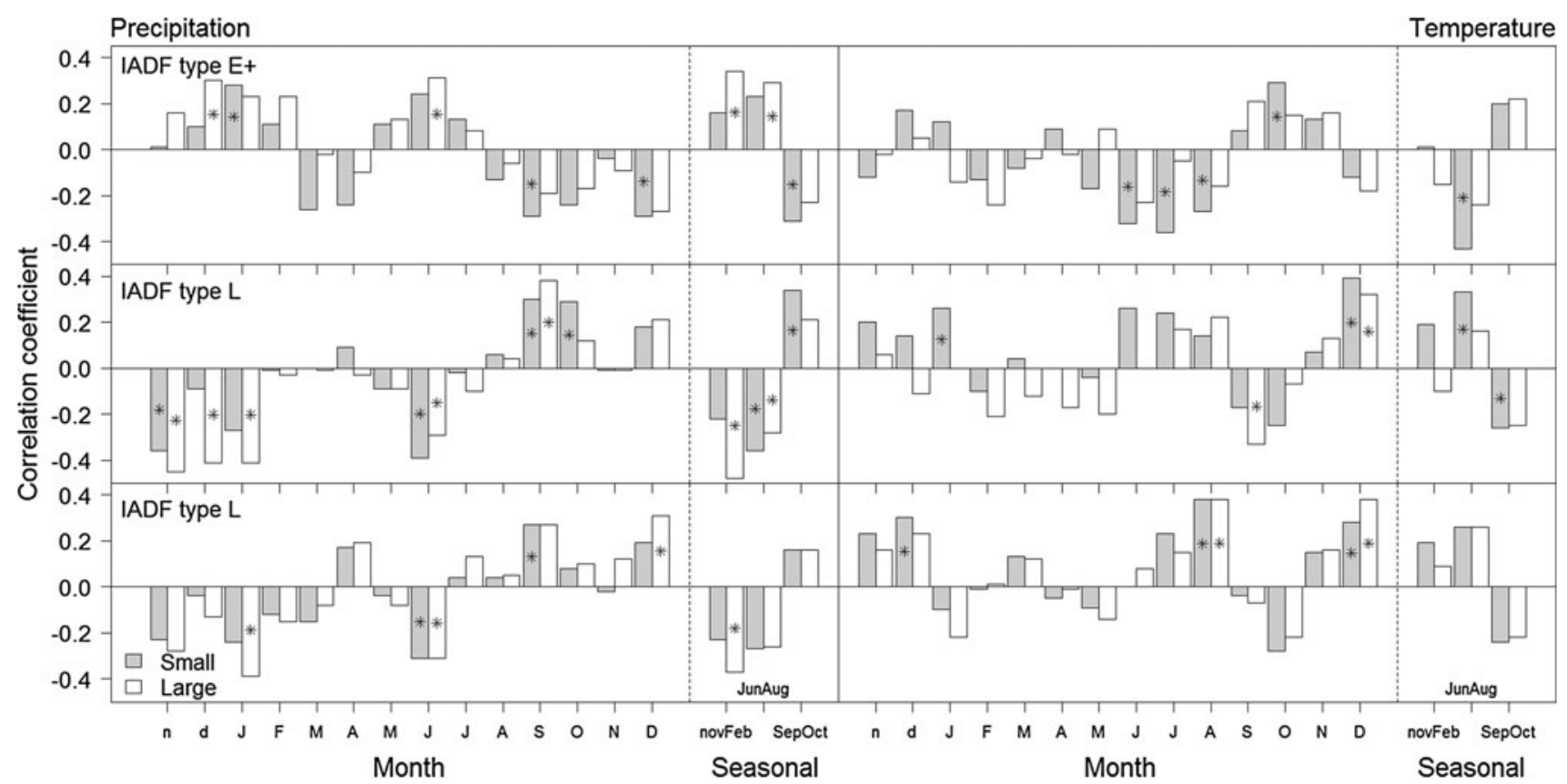

Fig. 7 Bootstrapped correlation coefficients between the chronologies of standardized frequency of intra-annual density fluctuations (IADF E $\mathrm{E}^{+}, \mathrm{IADF} \mathrm{L}_{\text {and IADF }}{ }^{+}$) for small and large diameter trees, and monthly/seasonal precipitation (left) and temperature (right) data from previous November to December of current year, for the period

dendrochronological studies have found that tree-ring growth of Pinus sp. at low elevations was limited by water availability during summer (Andreu et al. 2007; Bogino and Bravo 2008; Dorado Liñán et al. 2011). Tree-ring width of $P$. pinaster was positively correlated with precipitation in July in both size classes, but only smaller trees showed a negative correlation with the temperature of July. This can be due to differences in the dimension of the root system between the two size classes, with larger trees being able to exploit a larger area of soil, or deeper water resources, and consequently tree growth is more independent from evapotranspiration during summer, in contrast to smaller trees. Warmer temperatures in September enhanced tree growth by extending the growing season (Rathgeber et al. 2005; Touchan et al. 2012) and allowing a second growth peak after the summer drought (Camarero et al. 2010)

A high frequency of IADFs in $P$. pinaster was found in our study area, as it is expected for trees growing at low elevation, under Mediterranean climates, and with long growing seasons (Campelo et al. 2007; Vieira et al. 2009). Our results suggest that the growing season of $P$. pinaster should last for at least 8 months from March-April to November-December, as suggested by Rozas et al. (2011) for $P$. pinaster growing in NW Spain. For both size classes, a higher frequency of IADFs was observed in latewood rather than in earlywood, as previously observed in
1960-2008. An asterisk indicates a significant correlation at $p<0.05$. Capitals current-years months, lowercase prior-year months, novFeb prior November to current February, JunAug June to August, SepOct September to October

different species of the genus Pinus (Rigling et al. 2001; Campelo et al. 2007; Vieira et al. 2009; de Luis et al. 2011; Rozas et al. 2011), suggesting that the cambial activity is more controlled by the current environmental conditions during the second part of the growing season. In addition, trees of both size classes showed an increase in IADFs frequencies after 1980, as previously observed for this species by Bogino and Bravo (2009) in Spain and Vieira et al. (2010) in Portugal. In P. pinaster, IADFs were more frequent in larger trees (wider tree rings) than in smaller trees (narrower tree rings), as was also found in other studies (Rigling et al. 2001; Hoffer and Tardif 2009; Vieira et al. 2009). Wider rings can be formed due to a higher rate of cell production of the cambium (Rathgeber et al. 2011) and/or a longer growing season (Rossi et al. 2008; Linares et al. 2009; Lupi et al. 2010). According to Rathgeber et al. (2011) and Linares et al. (2009), the cambial activity of smaller trees starts later and finishes earlier, and has lower rates of cell production. Thus, the time window to record climatic variability is smaller and a less plastic response of small trees to climate should be expected and, consequently, a lower occurrence of IADFs. Nonetheless, our data showed that IADFs from different size classes contain a similar climatic signal.

Different types of IADFs can reveal the climatic conditions during the growing season (Campelo et al. 2007; de Micco et al. 2012), with some signals not captured by the 
tree-ring width chronologies (Wimmer et al. 2000; Hoffer and Tardif 2009; Edmondson 2010). The formation of IADF type $\mathrm{E}^{+}$represents a gradual transition between earlywood to latewood and is related to a later start of "true" latewood formation. The start of latewood formation is induced by shortening of the photoperiod and water stress (Vaganov et al. 2006), and is associated with slower rates of cell division, lower rates of cell expansion, and longer duration of secondary wall deposition (Uggla et al. 2001). In the study area, the transition from earlywood to latewood should occur around June, when water stress increases due to high evapotranspiration and/or depletion of the soil water storage. Water stress directly affects growth by inhibiting cell division and enlargement (Abe and Nakai 1999; Zweifel et al. 2006) and increasing the allocation of carbon to cellulose and lignin biosynthesis (Paiva et al. 2008). In $P$. pinaster, the formation of the IADF type $\mathrm{E}^{+}$was triggered by above-average precipitation in the previous winter in both size classes. High water availability at the beginning of the growing season can induce a higher rate of cambial division resulting in more tracheids under differentiation at the start of the summer (Lupi et al. 2010). This will probably result in the formation of an IADF type $\mathrm{E}^{+}$, with a smoother earlywood to latewood transition. Previous studies in loblolly pine showed that a wet summer also induced a more gradual transition between earlywood and latewood (Jayawickrama et al. 1997). In large trees, IADF type $\mathrm{E}^{+}$was triggered by high precipitation in June-August, whereas in small trees it was negatively correlated to temperature from June to August, suggesting that the formation of IADF $\mathrm{E}^{+}$was size-mediated. High temperatures in summer, associated with low precipitation, increase evapotranspiration and reduce soil moisture, which can induce an abrupt transition from earlywood to latewood, thus reducing the frequency of IADF type $\mathrm{E}^{+}$in small trees. Large trees probably have access to deeper water resources due to a more developed root system, and thus the formation of IADF type $\mathrm{E}^{+}$was less affected by summer temperatures.

The formation of IADF type $\mathrm{L}$ in both size classes was enhanced by low precipitation in the previous winter and current summer and high precipitation in autumn. Low winter precipitation reduces moisture availability during the next growing season, increasing water stress, especially noticeable during the summer, slowing down cambial activity and causing an earlier start of latewood formation. Larger trees were more sensitive to winter precipitation, and this can be an indication that they rely more on deep water reserves. High precipitation during late summer/early autumn can interrupt the cambial dormancy due to water stress, and new cells can be produced (Masiokas and Villalba 2004; Camarero et al. 2010; Battipaglia et al. 2010). In this case, IADF type L corresponds to a second growth peak, as observed in other conifers growing in the Mediterranean area (Camarero et al. 2010).

IADF type $\mathrm{L}^{+}$looks like "lighter" or "unfinished latewood", because tracheids seemingly do not reach full maturity (Vieira et al. 2009). In both size classes, the formation of IADF $\mathrm{L}^{+}$was associated with low precipitation in June and high temperatures in August. These climatic conditions could reduce the photosynthetic capacity (Medlyn et al. 2002), reducing the amount of carbohydrates that would be available for cell walls deposition at the end of the growing season, inducing the formation of IADFs type $\mathrm{L}^{+}$. Small trees showed a positive correlation between the frequency of latewood IADFs and temperature in $\operatorname{December}_{(t-1)}$ and January. We hypothesize that high temperatures before the growing season, when photosynthetic activity is low, could increase respiratory processes and reduce carbohydrate reserves, which are probably lower in smaller trees, decreasing the carbon available to build-up cell walls later in the season. The positive correlations between December $_{(t)}$ temperature and IADFs of type $\mathrm{L}$ and $\mathrm{L}^{+}$suggest that cells can continue differentiation until the end of the year or even all year round. For example, de Luis et al. (2011) observed that latewood tracheids of $P$. halepensis were still differentiating in December, demonstrating that warm winters could extend the period of cell differentiation.

The functional role of IADFs in trees remains an open question. Does it constitute a hydraulic adjustment of trees? It is known that vulnerability to cavitation and conductance efficiency is affected by the structure of the xylem (Domec and Gartner 2002). De Micco et al. (2007) stated that in the last portion of the earlywood (IADF type $\mathrm{E}^{+}$) of $P$. pinaster the theoretical water flow rate is lower than in "true" earlywood but higher than in latewood. A small increase in tracheid lumen area causes a fourth-power increase in hydraulic conductivity, as predicted by the HagenPoiseuille equation (Zimmermann 1983). Utsumi et al. (2003) found that by the end of summer many tracheids in the transition zone from earlywood to latewood of the outermost ring have no water inside. We hypothesize that an IADF type $\mathrm{E}^{+}$would be a gradual hydraulic adjustment to the summer drought, being less vulnerable to cavitation. Do latewood IADFs function as water storage compartments? The water uptake in earlywood tracheids is linearly related with the water loss by the leaves (Domec and Gartner 2002) and thus they do not constitute a water storage compartment, contrary to latewood tracheids that have a higher water storage capacity. Tracheids of latewood IADFs are earlywood-like cells, thus with larger diameters and higher hydraulic efficiency than 'true' latewood cells (Domec and Gartner 2002; Deslauriers et al. 2008). Latewood IADFs could increase the hydraulic conductance late in the growing season or increase the 
water storage capacity of trees, due to their larger lumen area. Martinez-Meier et al. (2008) suggested that trees without the capacity to change their density in response to climatic fluctuations over the growing season would be more vulnerable to drought. In our study, the frequencies of IADFs were considerably lower than those observed in $P$. pinaster in northeast Spain under a temperate climate (Rozas et al. 2011), but higher than those found in a southern location under Mediterranean climate (Vieira et al. 2009, 2010), suggesting a north-south gradient for the occurrence of IADFs. Therefore, an assessment of the individual phenotypic plasticity to climate and how this response affects hydraulic conductivity, embolism vulnerability, and internal water storage capacity will be necessary to elucidate the importance of IADFs under a climate change scenario.

Acknowledgments The authors wish to thank the communicating editor and two anonymous reviewers for their suggestions and comments that helped to improve the original version of the paper. This study was supported by the Portuguese Foundation for Science and Technology (FCT), through a postdoctoral research grant (SFRH/BPD/ 47822/2008) attributed to Filipe Campelo and a PhD grant (SFRH/BD/ 48089/2008) attributed to Joana Vieira, with funds from POPH (Portuguese Operational Human Potential Program) and QREN Portugal (Portuguese National Strategic Reference Framework).

\section{References}

Abe H, Nakai T (1999) Effect of the water status within a tree on tracheid morphogenesis in Cryptomeria japonica D. Don. Trees 14:124-129. doi:10.1007/PL00009758

Andreu L, Gutiérrez E, Macias M, Ribas M, Bosh O, Camarero JJ (2007) Climate increases regional tree-growth variability in Iberian pine forests. Glob Change Biol 13:804-815. doi:10.1111/ j.1365-2486.2007.01322.x

Battipaglia G, De Micco V, Brand WA, Linke P, Aronne G, Saurer M, Cherubini P (2010) Variations of vessel diameter and $\delta^{13} \mathrm{C}$ in false rings of Arbutus unedo L. reflect different environmental conditions. New Phytol 188:1099-1112. doi:10.1111/j.14698137.2010.03443.x

Bogino SM, Bravo F (2008) Growth response of Pinus pinaster Ait. to climatic variables in central Spanish forests. Ann For Sci 65:506. doi:10.1051/forest

Bogino S, Bravo F (2009) Climate and intraannual density fluctuations in Pinus pinaster subsp. mesogeensis in Spanish woodlands. Can J For Res 39:1557-1565

Briffa KR, Jones PD (1990) Basic chronology statistics and assessment. In: Cook ER, Kairiukstis LA (eds) Methods of dendrochronology: applications in the environmental sciences. Kluwer Academic Publishers, Boston, pp 137-152

Bunn A (2008) A dendrochronology program library in R (dplR). Dendrochronologia 26:115-124. doi:10.1016/j.dendro.2008.01.002

Camarero JJ, Olano JM, Parras A (2010) Plastic bimodal xylogenesis in conifers from continental Mediterranean climates. New Phytol 185:471-480. doi:10.1111/j.1469-8137.2009.03073.x

Campelo F, Nabais C, Freitas H, Gutiérrez E (2007) Climatic significance of tree-ring width and intra-annual density fluctuations in Pinus pinea from a dry Mediterranean area in Portugal. Ann For Sci 64:229-238. doi:10.1051/forest
Campelo F, García-González I, Nabais C (2012) detrendeR-a graphical user interface to process and visualize tree-ring data using $\mathrm{R}$. Dendrochronologia 30:57-60. doi:10.1016/j.dendro.2011.01.010

Carrer M, Urbinati C (2004) Age-dependent tree-ring growth responses to climate in Larix decidua and Pinus cembra. Ecology 85:730-740. doi:10.1890/02-0478

Chhin S, Hogg E, Lieffers V, Huang S (2008) Potential effects of climate change on the growth of lodgepole pine across diameter size classes and ecological regions. For Ecol Manag 256:1692-1703. doi:10.1016/j.foreco.2008.02.046

De Luis M, Gričar J, Čufar K, Raventós J (2007) Seasonal dynamics of wood formation: a comparison between pinning, microcoring and dendrometer measurements. IAWA J 28:389-404

De Luis M, Novak K, Čufar K, Raventós J (2009) Size mediated climate-growth relationships in Pinus halepensis and Pinus pinea. Trees 23:1065-1073. doi:10.1007/s00468-009-0349-5

De Luis M, Novak K, Raventós J, Gričar J, Prislan P, Čufar K (2011) Climate factors promoting intra-annual density fluctuations in Aleppo pine (Pinus halepensis) from semiarid sites. Dendrochronologia 29:163-169. doi:10.1016/j.dendro.2011.01.005

De Micco V, Saurer M, Aronne G, Tognetti R, Cherubini P (2007) Variations of wood anatomy and $\delta^{13} \mathrm{C}$ within-tree rings of coastal Pinus pinaster showing intra-annual density fluctuations. IAWA J 28:61-74

De Micco V, Battipaglia G, Brand WA, Linke P, Saurer M, Aronne G, Cherubini P (2012) Discrete versus continuous analysis of anatomical and $\delta^{13} \mathrm{C}$ variability in tree rings with intra-annual density fluctuations. Trees 26:513-524. doi:10.1007/s00468011-0612-4

Deslauriers A, Rossi S, Anfodillo T, Saracino A (2008) Cambial phenology, wood formation and temperature thresholds in two contrasting years at high altitude in southern Italy. Tree Physiol 28:863-871

Domec J-C, Gartner BL (2002) How do water transport and water storage differ in coniferous earlywood and latewood? J Exp Bot 53:2369-2379. doi:10.1093/jxb/erf100

Dorado Liñán I, Gutiérrez E, Heinrich I, Andreu-Hayles L, Muntán E, Campelo F, Helle G (2011) Age effects and climate response in trees: a multi-proxy tree-ring test in old-growth life stages. Eur J For Res 131:933-944. doi:10.1007/s10342-011-0566-5

Edmondson J (2010) The meteorological significance of false rings in eastern redcedar (Juniperus virginiana L.) from the southern Great Plains, U.S.A. Tree Ring Res 66:19-33

Esper J, Niederer R, Bebi P, Frank D (2008) Climate signal age effects-evidence from young and old trees in the Swiss Engadin. For Ecol Manag 255:3783-3789. doi:10.1016/j.foreco. 2008.03.015

Griffin D, Meko DM, Touchan R, Leavitt SW, Woodhouse CA (2011) Latewood chronology development for summer-moisture reconstruction in the U.S. Southwest. Tree Ring Res 67:87-101. doi: 10.3959/2011-4.1

He J-S, Zhang Q-B, Bazzaz FA (2005) Differential drought responses between saplings and adult trees in four co-occurring species of New England. Trees 19:442-450. doi:10.1007/s00468-004-0403-2

Hoffer M, Tardif JC (2009) False rings in jack pine and black spruce trees from eastern Manitoba as indicators of dry summers. Can J For Res 39:1722-1736. doi:10.1139/X09-088

Jayawickrama KJS, Mckeand SE, Jett JB, Wheeler EA (1997) Date of earlywood-latewood transition in provenances and families of loblolly pine, and its relationship to growth phenology and juvenile wood specific gravity. Can J For Res 27:1245-1253

Larson PR (1994) The vascular cambium: development and structure. Springer, Berlin

Linares JC, Camarero JJ, Carreira JA (2009) Plastic responses of Abies pinsapo xylogenesis to drought and competition. Tree Physiol 29:1525-1536. doi:10.1093/treephys/tpp084 
Liu C (1986) Rectifying radii on off-center increment cores. For Sci 32:1058-1061

Lupi C, Morin H, Deslauriers A, Rossi S (2010) Xylem phenology and wood production: resolving the chicken-or-egg dilemma. Plant Cell Environ 33:1721-1730. doi:10.1111/j.1365-3040. 2010.02176.x

Martinez-Meier A, Sanchez L, Pastorino M, Gallo L, Rozenberg P (2008) What is hot in tree rings? The wood density of surviving Douglas-firs to the 2003 drought and heat wave. For Ecol Manag 256:837-843. doi:10.1016/j.foreco.2008.05.041

Masiokas M, Villalba R (2004) Climatic significance of intra-annual bands in the wood of Nothofagus pumilio in southern Patagonia. Trees 18:696-704. doi:10.1007/s00468-004-0355-6

Medlyn BE, Loustau D, Delzon S (2002) Temperature response of parameters of a biochemically based model of photosynthesis. I. Seasonal changes in mature maritime pine (Pinus pinaster Ait.). Plant Cell Environ 25:1155-1165. doi:10.1046/j.13653040.2002.00890.x

Mérian P, Lebourgeois F (2011) Size-mediated climate-growth relationships in temperate forests: a multi-species analysis. For Ecol Manag 261:1382-1391. doi:10.1016/j.foreco.2011.01.019

Meyer FD, Braker OU (2001) Climate response in dominant and suppressed spruce trees, Picea abies (L.) Karst., on a subalpine and lower montane site in Switzerland. Ecoscience 8:105-114

Osborn TJ, Briffa KR, Jones PD (1997) Adjusting variance for sample-size in tree-ring chronologies and other regional mean time series. Dendrochronologia 15:89-99

Paiva JAP, Garnier-Géré PH, Rodrigues JC, Alves A, Santos S, Graça J, Le Provost G, Chaumeil G, Da Silva-Perez D, Bosc A, Fevereiro P, Plomion C (2008) Plasticity of maritime pine (Pinus pinaster) wood-forming tissues during a growing season. New Phytol 179:1080-1094. doi:10.1111/j.1469-8137.2008.02536.x

Pereira JS (2002) Pinus pinaster. In: Pines of silvicultural importance: compiled from the Forestry Compendium, CAB International. CABI Publishing, New York, pp 316-328

Pichler P, Oberhuber W (2007) Radial growth response of coniferous forest trees in an inner Alpine environment to heat-wave in 2003. For Ecol Manag 242:688-699. doi:10.1016/j.foreco.2007.02.007

Rathgeber CBK, Misson L, Nicault A, Guiot J (2005) Bioclimatic model of tree radial growth: application to the French Mediterranean Aleppo pine forests. Trees 19:162-176. doi:10.1007/ s00468-004-0378-z

Rathgeber CBK, Rossi S, Bontemps J-D (2011) Cambial activity related to tree size in a mature silver-fir plantation. Ann Bot 108:429-438. doi:10.1093/aob/mcr168

Rigling A, Waldner PO, Forster T, Bräker OU, Pouttu A (2001) Ecological interpretation of tree-ring width and intraannual density fluctuations in Pinus sylvestris on dry sites in the central Alps and Siberia. Can J For Res 31:18-31. doi:10.1139/cjfr-31-1-18

Rinn F (2003) TSAP-Win: Time series analysis and presentation for dendrochronology and related applications. Version 0.53 for Microsoft Windows. User Reference. Rinntech Heidelberg, Heidelberg, p 91

Rossi S, Deslauriers A, Anfodillo T, Carrer M (2008) Age-dependent xylogenesis in timberline conifers. New Phytol 177:199-208. doi:10.1111/j.1469-8137.2007.02235.x
Rozas V, García-González I, Zas R (2011) Climatic control of intraannual wood density fluctuations of Pinus pinaster in NW Spain. Trees 25:443-453. doi:10.1007/s00468-010-0519-5

Stokes MA, Smiley TC (1996) An introduction to tree-ring dating. The University of Arizona Press, Tucson

Szeicz JM, MacDonald GM (1994) Age-dependent tree-ring growth responses of subarctic white spruce to climate. Can J For Res 24:120-132

Touchan R, Shishov VV, Meko DM, Nouiri I, Grachev A (2012) Process based model sheds light on climate sensitivity of Mediterranean tree-ring width. Biogeosciences 9:965-972. doi: 10.5194/bg-9-965-2012

Uggla C, Magel E, Moritz T, Sundberg B (2001) Function and dynamics of auxin and carbohydrates during earlywood/latewood transition in Scots pine. Plant Physiol 125:2029-2039

Utsumi Y, Sano Y, Funada R, Ohtani J, Fujikawa S (2003) Seasonal and perennial changes in the distribution of water in the sapwood of conifers in a sub-frigid zone. Plant Physiol 131:1826-1833. doi:10.1104/pp.102.014795.large

Vaganov E, Hughes M, Shashkin A (2006) (2006) Growth dynamics of conifer tree rings. Springer, Heidelberg

Vieira J, Campelo F, Nabais C (2009) Age-dependent responses of tree-ring growth and intra-annual density fluctuations of Pinus pinaster to Mediterranean climate. Trees 23:257-265. doi: 10.1007/s00468-008-0273-0

Vieira J, Campelo F, Nabais C (2010) Intra-annual density fluctuations of Pinus pinaster are a record of climatic changes in the western Mediterranean region. Can J For Res 40:1567-1575. doi:10.1139/X10-096

Wang X, Zhang Y, McRae DJ (2009) Spatial and age-dependent treering growth responses of Larix gmelinii to climate in northeastern China. Trees 23:875-885. doi:10.1007/s00468-009-0329-9

Wigley TML, Briffa KR, Jones PD (1984) On the average value correlated time series, with applications in dendrochronology and hydrometeorology. J Clim Appl Meteorol 23:201-2013

Wimmer R (2002) Wood anatomical features in tree-rings as indicators of environmental change. Dendrochronologia 20:21-36. doi:10.1078/1125-7865-00005

Wimmer R, Strumia G, Holawe F (2000) Use of false rings in Austrian pine to reconstruct early growing season precipitation. Can J For Res 30:1691-1697. doi:10.1139/cjfr-30-11-1691

Xing P, Zhang Q, Baker PJ (2012) Age and radial growth pattern of four tree species in a subtropical forest of China. Trees 26:283-290. doi:10.1007/s00468-011-0590-6

Yu G, Liu Y, Wang X, Ma K (2008) Age-dependent tree-ring growth responses to climate in Qilian juniper (Sabina przewalskii Kom.). Trees 22:197-204. doi:10.1007/s00468-007-0170-y

Zimmermann MH (1983) Xylem structure and the ascent of sap. Springer, Berlin

Zweifel R, Zimmermann L, Zeugin F, Newbery DM (2006) Intraannual radial growth and water relations of trees: implications towards a growth mechanism. J Exp Bot 57:1445-1459. doi: $10.1093 / \mathrm{j} x \mathrm{~b} / \mathrm{erj} 125$ 